\title{
Teaching Internship Program for the Development of Student Teachers' Pedagogical Competence: Students' Voices
}

\author{
Irani Manasikana, Hartono* \\ English Education Department, Faculty of Languages and Communication Science, \\ Universitas Islam Sultan Agung (UNISSULA), Semarang, Indonesia \\ *Corresponding Author \\ Email: hartono@unissula.ac.id \\ Received: \\ 17 August 2021 \\ Revised: \\ 13 December 2021 \\ Accepted: \\ 21 December 2021 \\ Published: \\ 31 December 2021

\begin{abstract}
This study investigated English Education student teachers' voices about teaching internship programs to develop their pedagogical competence. The study involved 29 English student teachers of an English Education study program who were selected purposively after they completed their internship programs. A mixed-method research design was adopted, and data were collected by a questionnaire and interviews. The finding suggests that the internship program helped them develop their pedagogical competence. The mean score of the questionnaire to measure their perception of the benefit of the internship program was 64.21 , which belongs to the high category. Eighteen (18) respondents $(62.07 \%)$ perceived that the program highly developed their pedagogical competence and the rest (37.93) perceived it moderately did. No respondent perceived that it had a low effect on the development of their pedagogical competence. The qualitative data also suggest that the student teachers could positively benefit from the internship program in terms of their improved understanding of students' strengths and weaknesses, their understanding of curriculum and syllabus, teaching media, and teaching strategy to improve the learning process. With all the positive effects, a teaching internship program can be a tangible facility to improve pedagogical competence.
\end{abstract}

Keywords: teaching internship; pedagogical competence

\section{INTRODUCTION}

Students' learning outcomes are affected by many factors. One of them, which is considered very important, is the teachers' ability to deliver learning materials to the students, or commonly referred to as pedagogical competence (Faidal et al., 2020). It is a teacher's ability to use a coordinated and synergetic combination of tangible resources and intangible resources so that teaching goals can be effectively and efficiently achieved (Madhavaram \& Laverie, 2010). Tangible resources for teaching are, among others, learning materials and technology. While the intangible resources are teachers' knowledge, skills, and experience. Pedagogical competence should be mastered by teachers because it determines the success of teaching (Anwar et al., 2020). Furthermore, pedagogical competence consists of five components: Content knowledge, pedagogical approaches, course management capability, classroom management capability, and student management capability. Pedagogical practice in the form of teaching skill is a cycle of the observation of teaching and learning, knowledge of teaching and learning, and planning of teaching (Olsson \& Roxa, 2010). Pedagogical competence requires a good, broad, and deep understanding of the subject being taught and the ability to teach that supports students' learning.

To improve student teachers' pedagogical competence and other related competence, knowledge, and experience, teacher education programs send student teachers to have internship 
work at schools for a certain period. This teaching internship program is a vital and critical phase and becomes an integral component in making them more familiar and better equipped with the teaching jobs as they have opportunities to get immersed in an actual classroom experience (Rogayan \& Reusia, 2021). As a continuous experience, a teaching internship enhances student teachers' instructional and pedagogical skills. It reinforces and strengthens knowledge they have already got during their course work in the classrooms (Salviana et al., 2018). By having an internship at school, student teachers have opportunities to try and experience the art of teaching in the actual teaching and learning environment under the guidance and supervision of a tutor teacher, so when they get into a real teaching job with real and actual responsibilities, they will be able to perform well (Kiggundu \& Nayimuli, 2009). The teaching practice during the internship program becomes the core of student teachers' preparation to enter the teaching profession. It gives them opportunities to have the real interface between studenthood and professional membership in a real classroom and school context. Student teachers will observe and learn the complexities of teaching by examining actions, goals, and expectations. In this way, student teachers will be able to develop pedagogical competence, content knowledge, and professional knowledge.

Every year, the English Education Study Program of Universitas Islam Sultan Agung sends students to have internship programs to schools, primarily senior high schools. There are three programs, namely Internship Program 1 focusing on school observation, Internship Program 2 focusing on instructional material preparation as lesson plans, materials, and assessment; and Internship Program 3, which is arranged to give student teachers experience to teach in the real classroom under guidance and facilitation of a tutor teacher and a supervising teacher form the study program. Internship Program 3, which lasts for two months, usually becomes a moment of truth; whether a student teacher has sufficient content knowledge, is ready to teach and interact with students, is bringing the right motivation to the classroom, etc. This program is usually anticipated with mixed reactions of eagerness and anxiety, readiness, and worrisome. This study was conducted to assess the effectiveness of the teaching internship program in improving student teachers' pedagogical competence. The research question proposed was: How do student teachers perceive the effectiveness of teaching internship programs in developing their pedagogical competence? Student pedagogical competence became the focus of the research because this competence is essential for the success of teaching and becomes the challenge in teacher professionalism in the $21^{\text {st }}$ century (Otaya et al., 2018)

\section{METHOD}

To better understand the phenomenon being studied, this study adopted a mixed method of sequential explanatory design (Creswell, 2014). In this design, quantitative data collection and analysis was conducted prior to qualitative data collection and analysis. The qualitative data collection was meant to further explore and understand the phenomenon under study. The researchers employed this research design due to the desire to describe student-teacher voices on teaching internship programs to develop pedagogical competence. The researchers used a questionnaire to collect the quantitative data and interviews to collect the qualitative ones.

\section{Respondents}

Twenty-nine students from the English Education study program who have just completed Teaching Internship Program 3 served as the respondents for the study. They were selected purposively to become the respondents. Purposive or judgment sampling is an intentional selection of sampling from participants because of the participants' criteria. In this study, the criteria for the inclusion of individuals to be the sample was the completion of Teaching Internship 3. The 29 students met the criteria and were willing to be the respondents for the study. 


\section{Instruments}

This study employed a closed-ended questionnaire and a semi-structured interview to collect the data. The researchers selected a closed-ended questionnaire because it requires a relatively easy and effective rating (Roopa \& Rani, 2012). The respondents can give a checkmark on the columns prepared by the researchers. The researchers used the Likert Scale to measure perception. A questionnaire with four scale models of agreement was adopted. Scale 1 indicates that the respondent strongly disagrees (SDA) with the statement proposed, Scale 2 indicates their disagreement (D), Scale 3 indicates agreement (A), and Scale 4 indicates strong agreement (SA). The questionnaire covers five dimensions of pedagogical competence: understanding learners, development of curriculum, lesson planning, implementation of educational learning, and evaluation of learning outcomes. For collecting qualitative data, a semi-structured interview was applied because of its flexibility. In this interview model, the researchers didn't strictly follow all questions listed. The questions evolve, and the researchers may develop the questions from the interviewees' answers.

\section{Procedures}

The data were collected by following the procedures. First, the researchers asked permission to distribute the questionnaire and interviewed the respondents. Secondly, they gave the respondents time to fill the questionnaire. Then, they had the interviews with them. Finally, the researchers collected the questionnaires, extracted the interviews, and analyzed the data.

\section{Data analysis}

Data of the questionnaire were analyzed through scoring, interpreting, and concluding. Firstly, each statement from the questionnaire was counted by entering the score obtained into SPSS. Then, the result was categorized as High, Moderate, and Low, as presented in Table 1.

Table 1. The mean score interpretation for the statement

\begin{tabular}{ll}
\hline Mean Score & Category \\
\hline $1-2$ & Low \\
$2.01-3.00$ & Moderate \\
$3.01-4$ & High \\
\hline
\end{tabular}

Next was analyzing the data of entire respondents. The data were analyzed using SPSS and categorized as High, Moderate, and Low. Table 2 presents the categorization criteria.

Table 2. Score categories for entire respondents

\begin{tabular}{cl}
\hline Mean Score & Category \\
\hline $20-40$ & Low \\
$41-60$ & Moderate \\
$61-80$ & High \\
\hline
\end{tabular}

Secondly, after gaining the overall results, the researchers described them, and finally, conclusions were drawn.

For the data of the interviews, the researchers played back the interview recorder repeatedly in order to transcribe the interviews and do some note-taking. Thus, the researchers could understand and interpret the information from respondents. 


\section{RESULTS}

This study collected data by applying a closed-ended questionnaire and semi-structured interviews. The results of the questionnaire are presented in Table 3. It shows the minimum score (Min), the maximum score (max), the mean score (mean), and the category it belongs to.

Table 3. The Descriptive Statistics of the questionnaire results

\begin{tabular}{|c|c|c|c|c|c|}
\hline Statements & $\mathrm{N}$ & Min & Max & Mean & Category \\
\hline $\begin{array}{l}\text { 1. I can recognize and understand the students well. I know } \\
\text { the stages of development they have reached. }\end{array}$ & 29 & 2.00 & 4.00 & 3.00 & Moderate \\
\hline $\begin{array}{l}\text { 2. I understand the students' strength and weaknesses and } \\
\text { the factors affecting them. }\end{array}$ & 29 & 2.00 & 4.00 & 2.96 & Moderate \\
\hline $\begin{array}{l}\text { 3. I know teaching is not just talking, and learning is not } \\
\text { just listening. I am able to know about what the students } \\
\text { want and how they can understand and utilize their } \\
\text { knowledge and skills. }\end{array}$ & 29 & 2.00 & 4.00 & 3.27 & High \\
\hline $\begin{array}{l}\text { 4. As an effective teacher, I can invite the students with } \\
\text { good conversation and comprehend them. The students } \\
\text { respect the differences and follow a variety of teaching } \\
\text { activities }\end{array}$ & 29 & 3.00 & 4.00 & 3.24 & High \\
\hline $\begin{array}{l}\text { 5. I can grasp the definition and the nature of the } \\
\text { curriculum that has been generally accepted. }\end{array}$ & 29 & 2.00 & 4.00 & 3.00 & Moderate \\
\hline $\begin{array}{l}\text { 6. As a curriculum developer, I do not forget the moral } \\
\text { aspect of the learning process. }\end{array}$ & 29 & 3.00 & 4.00 & 3.27 & High \\
\hline 7. I can use books as materials when teaching. & 29 & 2.00 & 4.00 & 3.20 & High \\
\hline $\begin{array}{l}\text { 8. I adjust the materials taught by using books that have } \\
\text { been standardized by National Education Standards. }\end{array}$ & 29 & 2.00 & 4.00 & 3.27 & High \\
\hline $\begin{array}{l}\text { 9. As an effective teacher, I can organize the class with the } \\
\text { proper procedures and think about what the students } \\
\text { should do. }\end{array}$ & 29 & 3.00 & 4.00 & 3.51 & High \\
\hline $\begin{array}{l}\text { 10. I know and understand what I teach to the students, and } \\
\text { I prepare instructional methods and media before teaching. }\end{array}$ & 29 & 3.00 & 4.00 & 3.37 & High \\
\hline 11. I make preparation before teaching. & 29 & 2.00 & 4.00 & 3.48 & High \\
\hline $\begin{array}{l}\text { 12. I give belief to students, and I motivate them to } \\
\text { emulate the goodness and the orderliness }\end{array}$ & 29 & 2.00 & 4.00 & 3.24 & High \\
\hline $\begin{array}{l}\text { 13. I raise initiatives to learn to students because generally, } \\
\text { they do not understand the importance of learning. } \\
\text { Afterwards, I prepare the lessons that attract their } \\
\text { curiosity. }\end{array}$ & 29 & 2.00 & 4.00 & 3.10 & High \\
\hline 14. I comprehend the students' progress in learning & 29 & 3.00 & 4.00 & 3.17 & High \\
\hline $\begin{array}{l}\text { 15. I give the students time to ask questions. Then I give } \\
\text { feedback on them. }\end{array}$ & 29 & 3.00 & 4.00 & 3.20 & High \\
\hline $\begin{array}{l}\text { 16. I make student activity towards what I teach and the } \\
\text { learning process that involves the students. }\end{array}$ & 29 & 3.00 & 4.00 & 3.44 & High \\
\hline $\begin{array}{l}\text { 17. I explain to the students the results to achieve and the } \\
\text { importance of achieving learning objectives. }\end{array}$ & 29 & 3.00 & 4.00 & 3.13 & High \\
\hline $\begin{array}{l}\text { 18. I have students' documents and information processing } \\
\text { to measure the achievement of students' learning outcomes }\end{array}$ & 29 & 3.00 & 4.00 & 3.20 & High \\
\hline $\begin{array}{l}\text { 19. I assess the learning outcomes by including the } \\
\text { cognitive aspect, appropriate characteristics, and } \\
\text { psychomotor. }\end{array}$ & 29 & 2.00 & 4.00 & 3.20 & High \\
\hline $\begin{array}{l}\text { 20. I provide the services students need inside and outside } \\
\text { the classroom. }\end{array}$ & 29 & 2.00 & 4.00 & 2.86 & Moderate \\
\hline Valid N (listwise) & 29 & & & & \\
\hline
\end{tabular}

Table 3 presents the respondents' ability on pedagogical competence. The respondents have a high category on 16 statements and have a moderate category on 4 statements. The first highest mean score was "As an effective teacher, I organize the class with the proper procedures 
and think about what the students should do." The mean score is 3.51. It implies the student teachers believed they could develop their pedagogical skills in organizing the class. A class organization such as choosing the proper procedure is an essential indicator for the success of and the achievement of learning objectives. A good classroom organization becomes a measure of a teacher's success in teaching because it is a key element to reaching learning objectives. The second highest mean score was "I make preparation before teaching." The mean score is 3.48 . It means the student teachers were very confident that they could improve their pedagogical skills, particularly in making preparation before teaching. From the implication of pedagogical skill, this was the important thing in mastering learning principles starting from mastering theory and teaching material. By mastering teaching material, teachers will be able to deliver the materials clearly and appropriately. Thus, it is a must for a teacher to master the learning material before teaching.

Among the low scores, there are two statements at the bottom of the rank that need to be interpreted. The first was "I provide the services students need inside and outside the classroom," with a mean score of 2.86. It implies that the student teachers thought they still could not develop their pedagogical skills principally in providing the services to students inside and outside the class. As a facilitator and a tutor, the teacher must always be disposed to help students wherever they need. Because by doing so, the students shall be happy to do their homework because they feel guided. The second is "I understand the students' strengths and weakness and the factors affecting them," with a mean score of 2.96. It means that the student teachers thought they could not develop their pedagogical skills and understand their students' strengths and weaknesses. It is a key indicator to understand students in depth because this is a requirement for a teacher to design learning and determine appropriate learning strategies based on student characteristics. So, learning activity takes place in fun and easy ways, and learning objectives can finally be reached.

To know the general effect of teaching internship programs on the development of pedagogical competence, the total scores of the statements were analyzed descriptively. The result is presented in Table 4 and Table 5.

Table 4. Descriptive statistics of the results of the questionnaire

\begin{tabular}{lccccc}
\hline & N & Min & Max & Mean & Std. Deviation \\
\hline Total & 29 & 57.00 & 80.00 & 64.21 & 6.18 \\
Valid N (listwise) & 29 & & & & \\
\hline
\end{tabular}

Table 4 shows the minimum score of the respondents' overall scores for pedagogic competence is 57.00 , the maximum score is 80.00 , the mean score is 64.21 , and the standard deviation is 6.18 . By referring to the categorization criteria as presented in Table 2, it can be concluded that after having Teaching Internship Program 3, the students have a high level of pedagogical competence. This means that the internship program can help them develop and shape student teachers' pedagogical competence.

Further analysis shows that 11 students have a moderate level of pedagogical competence, 18 students have a high level of pedagogical competence, and none have a low level. Table 5 presents the data.

Table 5. Category of respondents' pedagogical competence

\begin{tabular}{llcccc}
\hline & & Freq. & $\%$ & valid \% & Cum. \% \\
\hline Valid & Moderate & 11 & 37.9 & 37.9 & 37.9 \\
& High & 18 & 62.1 & 62.1 & 100.0 \\
& Total & 29 & 100.0 & 100.0 & \\
\hline
\end{tabular}


The data show that respondents with a high pedagogical competence category outnumbered respondents with a moderate category. Therefore, it can be concluded that a teaching internship program could generally develop student teachers' pedagogical competence.

For qualitative data, the results of the interviews are presented. The researchers took 5 main questions to initiate the semi-structured interviews. Here are the results:

Question 1: What do you know and understand about your students?

Regarding the first question, the researchers found that most student teachers responded that teaching internships could help them understand students' strengths and weaknesses. They could also understand the factors affecting them during the learning process. The factors affecting the students the most were their old habits, their being unmotivated to have online learning, and some technical problems as they couldn't follow the online lessons very well because of a poor internet signal, which made the teacher's explanations explain could not fully be comprehended.

Question 2: What do you know about the curriculum or syllabus development?

Responding to this question, most student teachers claimed they knew the curriculum/syllabus development. They knew the natures of the current curriculum well, even though they did not mention the definition. Furthermore, as the implementation of the curriculum, the student teachers utilized books when teaching and enriched the learning materials with materials from the books that National Education Standard standardizes.

\section{Question 3: What do you prepare before teaching?}

All student teachers interviewed stated that they prepared instructional methods, media, and lesson plans under the guidance of their supervising teachers. They learned how to make lesson plans from their tutor, teachers, and internets. However, they found that the details of lesson plans required by the tutor teachers were not always the same. A tutor teacher, for example, insisted on the student teachers to make a very detailed and complete lesson plan, but another tutor teacher did not. This sometimes made the student teachers confused. From this experience, the student teachers might learn that different tutor teachers might use lessons differently.

Question 4: How can you help students to increase their learning process?

Almost all of the student teachers responded that they could help their students to increase learning progress by providing various types of student activities such as homework or exercise and providing them time to ask questions.

Question 5: How do you evaluate your students' learning outcomes?

The interview data indicated that the student teachers documented files of students' works and analysed them. In doing the analysis, they consulted their supervising teachers. The documents were scores, attendance lists, and notes they wrote during the teaching and learning process.

\section{DISCUSSION}

The purpose of this study was to answer the research question about the effectiveness of teaching internship programs to improve student teachers' pedagogical competence. The analysis of the quantitative data collected by the questionnaire concludes that after having the internship program, student teachers perceive a high level of pedagogical competence. The mean score of the questionnaire result is 64.21 , which belongs to the high category. This indicates that the program could help develop student teachers' pedagogical competence. The result also shows most respondents $(62.1 \%)$ rated teaching internship programs could highly develop their pedagogical competence. In comparison, only 11 respondents $(37.9 \%)$ rated teaching internship programs moderately improved their pedagogical competence. No respondent rated it low. So, in 
conclusion, students perceived that a teaching internship program could highly develop their pedagogical competence. Analysis of each statement in the questionnaire also reveals that 16 statements were rated "high," and only 4 statements were rated "moderate." This finding confirms the conclusion.

From the 16 highly rated statements, there were items of the statements considered standing out, were "As an effective teacher, I organize the class with the proper procedures and think about what the students should do" (3.51), "I make preparation before teaching" (3.48), "I make student activity towards what I teach, and the learning process should involve the students" (3.44), and "I know and understand what I teach to students, and I prepare instructional methods and media before teaching" (3.37). They were considered standing out because the mean scores were above the average. Therefore, most student teachers perceived that teaching internship programs could improve their pedagogical competence, especially those four aspects.

Apart from the questionnaire result, the researchers found the items standing out from the interview result. The first indicator was the student teachers' ability to understand their students. Most of them said they could understand their students' strengths and weaknesses and the factors affecting them. It referred to the statement, "I understand the students' strengths and weaknesses and the factor affecting them." Even the student teachers did not mention their students' strengths and weaknesses. Still, after being analysed indirectly, most of them knew enough about their students' strengths and weaknesses while they did not really understand them perfectly. This semi-structured interview result was in accordance with the close-ended questionnaire's moderate result.

The second indicator was the student teachers' ability to understand curriculum/syllabus development. Most of them answered that they understood and practiced all the items except on the statement, "As curriculum developers, I do not forget the moral aspect of the learning process." For the statement "I grasp the definition of curriculum and the nature of the curriculum that has been accepted generally," the researchers realized the student teachers quite knew the nature of the current curriculum being applied in the host schools. However, they did not mention the curriculum definition during the interview. Then, for the statement "I use books when teaching materials" and "I adjust the materials taught by using books that have been standardized by National Education Standards," most of the student teachers said they utilized books when teaching that was supported with power-point presentations and videos. In addition, the contents also had been adjusted with National Education Standard books.

The third indicator was student teachers' ability to understand lesson plans. The statements that the most standing out were "I know and understand what I teach to students, and I prepare instructional methods and media before teaching," "As an effective teacher, I organize the class with the proper procedures and think about what the students should do and how it should be done," and "I make preparation before teaching." They became standing out because most student teachers explained they prepared method, media, and lesson plan prepared themselves mentally, and mastered the teaching materials very well before teaching with the direction and the guidance from their tutor and supervising teachers. These three statements were also the most standing statements in the questionnaire result. Hence, the teaching internship program could improve student teachers' pedagogical skills, particularly understanding the lesson plan.

The fourth indicator was student teachers' ability to understand the implementation of educational learning. This indicator showed how the student teachers helped improve students' learning progress. The result was almost all the student teachers replied they could help their students' learning progress by giving various types of student activities such as exercises or homework and giving them time to ask a question. Principally, those statements pointed on the statements "I make student activity towards what I teach, and learning process should involve the students" and "I give the students time to ask questions. Then I give feedback on the students' 
questions". The results of the questionnaire and the interview both mentioned that student teachers supplied student activities to help their students improve their learning progress.

The last indicator was student teachers' capability to understand the evaluation of learning outcomes. Almost all the student teachers responded they had documents and information processing to be evaluated. This pointed in the statement, "I have students' documents and information processing to measure the achievement of students' learning outcomes."

From the various results of standing out statements, 4 items were mentioned equally prominently from the close-ended questionnaire and the semi-structured interview. They were "As an effective teacher, I organize the class with the proper procedures and think about what the students should do," "I know and understand what I teach to students, and I prepare instructional methods and media before teaching," "I make preparation before teaching." Those are the indicator of understanding the lesson plan. The statement "I make student activity towards what I teach, and learning process should involve the students" indicates understanding the implementation of educational learning. Thereupon, it was indicated that student teachers perceived the teaching internship program as good for developing pedagogical competence, especially on the understanding lesson plan and implementing learning activities.

This finding is in line with some previous research. The study of Tindowen et al. (2019), for example, found that teaching internship programs effectively help and develop students' hard and soft skills required in the teaching professions. The student-teachers of the study also found that teaching internship programs could make students responsive to the needs of changes in the schools. With specific treatment, internships could also develop teacher students' reflective ability to improve their teaching skills (Nagro et al., 2017). This study also supports the previous research finding that coaching the student teachers' experience during their internship program has improved their pedagogical skills (Dewi \& Kartowagiran, 2018).

\section{CONCLUSION}

This study investigated the student teachers' perception of the effect of the teaching internship program on developing their pedagogical competence. The data from the closed-ended questionnaire and the semi-structured interview show that the student teachers who participated in the study perceived that teaching internship could highly develop their pedagogical competence. The clear indicators that the student teachers could develop the competence were the understanding of the lesson plan, the implementation of educational learning, the understanding of the development of curriculum/syllabus, the understanding learners, and the understanding of the evaluation of learning outcomes. On understanding the lesson plan, the student teachers admitted that they were able to compose lesson plans, prepare methods and media before teaching, and get mentally prepared by mastering the material before starting teaching. On the understanding of the implementation of educational learning, the student teachers stated they could help improve the student learning progress by providing various kinds of student activities and giving them time to ask questions. This study shows teaching internship program can be a tangible facility to develop student teachers' pedagogical competence.

\section{ACKNOWLEDGEMENT}

The writers would like to thank the late Ibu Huyi Intan Sari for supporting and facilitating the writers to collect data for the study. She was a great lecturer. May Allah grant her Jannah. Aamiin. 
Anwar, C., Hartono, H., Faridi, A., Yuliasri, I., \& Pratama, H. (2020). Islamic undergraduate students' perceptions toward teacher's basic pedagogical competences at English tutorial class. In B. Santosa, H. Sulistyo, H. A. Pratiwi, \& C. Anwar (Eds.), The 1st International Conference on Islamic Civilization, ICIC 2020. European Union Digital Library. https://doi.org/10.4108/eai.27-8-2020.2303268

Creswell. (2014). Research Design Qualitative, Quantitative, and Mixed Methods Approaches (Vi. Knight, J. Young, \& K. Koscielak (eds.); 4th ed.). SAGE Pub.

Dewi, L. R., \& Kartowagiran, B. (2018). An evaluation of internship program by using Kirkpatrick evaluation model. Research and Evaluation in Education, 4(2), 155-163. https://doi.org/10.21831/reid.v4i2.22495

Faidal, N. F., Nur, R.-, \& Suriani, S. (2020). The teachers' pedagogic competence in teaching English through online and offline setting. ELT Worldwide: Journal of English Language Teaching, 7(1), 42. https://doi.org/10.26858/eltww.v7i1.13294

Kiggundu, E., \& Nayimuli, S. (2009). Teaching practice: A make or break phase for student teachers. South African Journal of Education, 29(3), 345-358. https://doi.org/10.15700/saje.v29n3a129

Madhavaram, S., \& Laverie, D. A. (2010). Developing pedagogical competence: Issues and implications for marketing education. Journal of Marketing Education, 32(2), 197-213. https://doi.org/10.1177/0273475309360162

Nagro, S. A., deBettencourt, L. U., Rosenberg, M. S., Carran, D. T., \& Weiss, M. P. (2017). The effects of guided video analysis on teacher candidates' reflective ability and instructional skills. Teacher Education and Special Education, 40(1), 7-25. https://doi.org/10.1177/0888406416680469

Olsson, T., \& Roxa, K. M. och T. (2010). Pedagogiacal competence - A development perspective from Lund University. In A. Ryegard, T. Olsson, \& K. Apelgren (Eds.), A Swedish Perspective on Pedagogical Competence (pp. 121-132). Uppsala University.

Otaya, L. G., Kartowagiran, B., \& Retnawati, H. (2018). Construct validity pedagogy competency instrument of teaching and learning practice program (TLPP) students: Unidimensional confirmatory factor analysis. International Journal of Advanced and Applied Sciences, 5(8), 24-33. https://doi.org/10.21833/ijaas.2018.08.004

Rogayan, D. V., \& Reusia, D. H. R. (2021). Teaching internship from the metaphorical lens of Filipino prospective teachers. International Journal of Evaluation and Research in Education, 10(3), 798-806. https://doi.org/10.11591/ijere.v10i3.21242

Roopa, S., \& Rani, M. (2012). Questionnaire designing for a survey. Journal of Indian Orthodontic Society, 46(4), 273-277. https://doi.org/10.1177/0974909820120509s

Salviana, Muslem, A., \& Bukhari, D. (2018). English student teachers' constraints during their teaching internship programs with English Department of FKIP Unsyiah in Aceh. English Education Journal (EEJ), 9(3), 466-489.

Tindowen, D. J., Bangi, J., \& Parallag, C. (2019). Pre-service teachers' evaluation on their student internship program. International Journal of Learning, Teaching and Educational Research, 18(10), 279-291. https://doi.org/10.26803/IJLTER.18.10.18 